\title{
Immune reconstitution inflammatory syndrome observed in the setting of drug-induced hypersensitivity syndrome/drug reaction with eosinophilia and systemic symptoms (DIHS/DRESS)
}

\author{
Yoko Kano*, Yukiko Ushigome, Chiho Horie, Yoshiko Mizukawa, Tetsuo Shiohara \\ From 6th Drug Hypersensitivity Meeting (DHM 6) \\ Bern, Switzerland. 9-12 April 2014
}

Immune reconstitution inflammatory syndrome (IRIS) is originally described in association with antiretroviral therapy (ART) for HIV infected patients. IRIS consists of a broad spectrum of inflammatory diseases, such as infectious inflammatory, neoplastic, and autoimmune diseases, that present after starting an effective ART, leading to $\mathrm{CD} 4+$ cells increase and plasma HIV-RNA reduction. IRIS reflects either worsening of an already-diagnosed infection or presentation of previously subclinical infection. Opportunistic pathogens include cryptococcus, mycobacterium, herpesviruses, or also auto-antigens. The paradoxical worsening of clinical symptoms as observed in IRIS is also the phenomenon of drug-induced hypersensitivity syndrome/ drug reaction with eosinophilia and systemic symptoms (DIHS/DRESS). In the course of DIHS/DRESS, cytomegalovirus diseases and herpes zoster are observed coincidently with the increase in lymphocytes or rapid reduction of systemic corticosteroids. Based on the similar manifestations between IRIS and DIHS/DRESS, DIHS/DRESS can be seen in a broad context as another manifestation of IRIS. Although the mechanisms of IRIS is complex and variable, depending on the latent pathogens and shift of immune status, use of the concept of IRIS can help our recognition of various manifestations that occur in the setting of DIHS/DRESS. The understanding of IRIS may improve the morbidity and mortality rates of DIHS/ DRESS.

Published: 18 July 2014

Kyorin University School of Medicine, Dermatology, Japan
doi:10.1186/2045-7022-4-S3-P148

Cite this article as: Kano et al:: Immune reconstitution inflammatory syndrome observed in the setting of drug-induced hypersensitivity syndrome/drug reaction with eosinophilia and systemic symptoms (DIHS/DRESS). Clinical and Translational Allergy 2014 4(Suppl 3):P148.
Submit your next manuscript to BioMed Central and take full advantage of:

- Convenient online submission

- Thorough peer review

- No space constraints or color figure charges

- Immediate publication on acceptance

- Inclusion in PubMed, CAS, Scopus and Google Scholar

- Research which is freely available for redistribution

Submit your manuscript at www.biomedcentral.com/submit
C Biomed Central 